\title{
Hydroxy Gas (HHO) Supplement of Ethanol Fuel Mixture In A Single-Cylinder Spark-Ignition Matic-Engine
}

\author{
Gatot Setyono, ${ }^{1, a}$, Ahmad Anas Arifin ${ }^{2, b}$ and Zain Lillahulhaq ${ }^{3, c}$ \\ 1,2,3 Departement of Mechanical Engineering, Adhi Tama Institute of Technology (ITATS) \\ 1,2,3 Jl. Arif Rahman Hakim No 100 Surabaya, Indonesia \\ agatot_mesin@itats.ac.id, banas.arifin10@gmail.com, ${ }^{c}$ zain@itats.ac.id
}

\begin{abstract}
Abstrak.
Hydroxy Gas (HHO) telah dikenal sebagai sumber energi alternatif yang efisien. HHO yang dianggap sebagai alternatif pengganti bahan bakar fosil atau dicampur dengan bahan bakar lain dalam rasio yang berbeda. Dalam penelitian ini, campuran Etanol-HHO yang memiliki tingkat oktan yang tinggi, emisi gas buang rendah, dan yang mudah diperoleh dari produk mesin yang diterapkan dengan rasio penambahan bahan bakar (E30-HHO, E40-HHO, dan E50-HHO). Campuran etanol-HHO telah diimplementasikan pada mesin bensin satu silinder untuk kinerja dalam beban penuh, kecepatan mesin bervariasi dari 4000-9000 rpm serta menggunakan busi elektroda platinum. Dalam eksperimen ini, hal yang perlu dianalisa adalah power mesin, tekanan efektif rata-rata (Mep), konsumsi bahan bakar spesifik (SFC), dan efisiensi termal. Pada analisis pembakaran ini, diaktualisasikan dengan menggunakan siklus tekanan dalam silinder, autoregulasi unit kontrol mesin dan pemanfaatan parameter yang sama dari berbagai bahan bakar yang diuji, dengan tambahan waktu injeksi bahan bakar, semakin meningkat dengan bertambahnya prosentase etanol. Daya maksimum, tekanan efektif rata-rata, dan nilai termal efisiensi diperoleh dengan campuran etanol-bensin (E50-HHO) dihasilkan pada putaran mesin $7200 \mathrm{rpm}$, meningkat sekitar 5\% dibandingkan dengan bahan bakar referensi. Penurunan yang signifikan dalam konsumsi bahan bakar spesifik yang dihasilkan dengan menggunakan campuran etanol-HHO, berkurang sekitar 6\% dibandingkan dengan bensin referensi.
\end{abstract}

Kata kunci. Gas Hydroxy (HHO), Etanol, Etanol-HHO dan Mesin-Matic.

\begin{abstract}
.
Hydroxy Gas (HHO) has been identified as an efficient alternative energy source. HHO is considered an alternative fuel. It can be applied alone or mixed with other kind of fuels in different ratios. In this analysis, the composition of HHO-ethanol was mixed in different variations. Ethanol-HHO was chosen because of its high-octane rating yet low exhaust emissions, and ease of obtaining from engine products. It has been applied on fuel prepared by mixing it with gasoline in various ratios (E30-HHO, E40-HHO, and E50-HHO). The ethanol-HHO mixture has been used in a single-cylinder 4-stroke spark machine for performance, by varying speed of engine from 4000 to 9000 RPM and by applying a platinum spark plug electrode type. In experiments, engine power, average effective pressure (MEP), specific fuel consumption (SFC), and thermal efficiency have been analyzed. The analysis of combustion is accomplished by taking a pressure cycle in the chamber, monitoring the automatic control of engine control unit (ECU) and ensuring utilization in the same parameters of the various fuels tested, in addition to the fuel injection time, which increases with increasing ethanol percentage. Optimal power, MEP and thermal efficiency values are obtained with ethanol-gasoline (E50-HHO) mixture which is operated at $7200 \mathrm{rpm}$, an increase of about 5\% compared to gasoline. Significant reduction in SFC was observed using HHO-ethanol mixture, reduced by about $6 \%$ compared to gasoline.
\end{abstract}

Keywords: Hydroxy Gas (HHO), Ethanol, Ethanol-HHO and Matic-Engine. 


\section{Introduction}

Fossil fuel usage is constantly rising in industrial as well as in the transportation sector as a yield of population growth in extension to improvements in the standard of living. The steadily decreasing resources of fossil fuel and the highly toxic emissions which are generated due to these fuels have mainly expedited the need for alternate fuels for internal combustion engines (ICE). Several fuels have been attempted for requesting internal combustion engines. These contain lank vegetable oil, biodiesel, alcohol, natural gas, and hydrogen. Hydrogen has been established to have several properties which are essential for a green option fuel to be applied in IC engines. Its high auto-ignition temperature and low ignition energy paired with its varied other combustive properties assist in increasing engine performance. The advanced diffusivity of hydrogen which is about four times that of gasoline fixes the blending process of fuel and air. The actual indicator diagram is more imminent to ideal diagram and thermodynamic efficiency intensify when burning velocity increases [1]. The trending global attention for reducing consumption of fuel and emissions of ICE is encouraging scholars to search solutions that would not involve a dramatic transformation on deign of engine. Amongst such solutions are utilizing $\mathrm{H} 2$ for an alternative option fuel to supplement efficiency of engine and generate lesser pollution [2]. It is not proper from a commercial point of view, constructing a system which produces $\mathrm{H} 2$ and combining it with the engine system yields a high manufacturing cost [3].

The effect of the addition of HHO on the IC engine was investigated by Yilmaz et al [4]. Their yields reported an increase in engine torque by an average of $19.1 \%$, reduction in $\mathrm{CO}$ and $\mathrm{HC}$ emissions, and Specific Fuel Consumption by an average of 13.5\%, 5\%, and 14\%, respectively [4]. The benefits of $\mathrm{CO} 2, \mathrm{CO}$, and $\mathrm{HC}$ decrease, while NOx increases, with a higher $\mathrm{H} 2$, it will be caused by the following: this decrease in 3 is linked to an increased combustion kinetics, because $\mathrm{H} 2$ combustion produces beneficial $\mathrm{OH}$ and $\mathrm{O}$ radical oxidizing species. chemical combustion of Hydrocarbons (HCs). Besides, the flow of gasoline fuel is reduced by $\mathrm{H} 2$ enrichment to maintain a constant global mix equality and to compare engine performance with pure gasoline, so that a lower rate of HCs is present in the fuel, which cuts the formation of $\mathrm{CO}, \mathrm{CO} 2$, and $\mathrm{HC}$ and drives fuel consumption economy. Furthermore, hydrogen has a higher distribution coefficient than gasoline, and as such, H2 gas can be completely dispersed in the load and authorizes greater mixture homogeneity and combustion completeness. On the other hand, NOx escalate is associated with higher adiabatic hydrogen flame temperatures [5]. Hydrogen has a higher flame speed and the mixture of gasoline can burn faster. However, because $\mathrm{H} 2$ supplements expand the combustible limit of the mixture to a leaner fuel equality, the reaction rate will decrease and combustion will be extended under lean conditions [6].

Ethanol is studied as an alternative fuel for the Spark-Ignition engine and is known for producing blends with gasoline. The experimental investigations carried out on the engine are a four-step cycle, one cylinder, $124.8 \mathrm{~cm} 3$ engine volume, port fuel injection, a 9.3: 1 compression ratio, and a large Euro 3 motorcycle that is triggered by commercial gasoline with Research Octane Number (RON) 95 and ethanol/gasoline mixture G45, G35, G55, (within range 45\%, 35\%, and 25\%) Maximum power, means effective pressure and thermal efficiency values obtained with the ethanol-gasoline (G45) mixture position with the effort 7000 RPM. Significantly reduced specific fuel consumption was seen using ethanol-gasoline mixture G45 (45\%) [7]. One of the main objectives of this 
experimental investigation is to examine the consequences of gas-hydroxy enrichment on alternative fuels that are environmentally friendly but reduce performance such as ethanol and diesohol. Gas of hydroxy is the result of the pure water electrolysis method. The entire HHO system has been integrated into the engine test rig for this motive. Two different mixtures of diesohol fuels are organized and named according to their volumetric composition. Biodiesel is used to represent biodiesel, ethanol and standard diesel blends [8]. Hybrid internal combustion engines that utilize HHO gas are considered as one of the most important applications studied. Engine performance and gas emissions are explored for two different engines; $150 \mathrm{~cm} 3$ with a carburetor and $1300 \mathrm{~cm} 3$ with an Electronic Control Unit (ECU). The results noted that fuel consumption was degraded by $14.8 \%$ for $150 \mathrm{~cm} 3$ engines and $16.3 \%$ for $1,300 \mathrm{~cm} 3$ engines. $\mathrm{HHO}$ gas reduces emitted gas (net production) by $33 \%$ and $24.5 \%$ reduction in $\mathrm{CO}$ and $27.4 \%$ and $21 \%$ decrease in $\mathrm{HC}$ for $150 \mathrm{~cm} 3$ and $1300 \mathrm{~cm} 3$, respectively. The new application of $\mathrm{HHO}$ gas is to use it in water desalination. Hybrid solar which still uses oxy-hydrogen is investigated and the productivity of distilled water is examined [9].

Analysis of combustion, performance, and emissions from various mix ratios of liquid test fuel mixtures within the scope of the study is in the literature. Researchers generally focus on increasing emissions. However, an analysis of the performance of the fuel mixture is available in the disclosure literature. As a result of several independent studies by various researchers, it was resolvedd that ethanol tends to increase power, torque, and reduce fuel consumption. This situation has been tried to compensate by creating structural changes to the engine. The enrichment of a mixture of ethanol fuel with pure hydrogen has been examined by scholars in the literature. However, the HHO enrichment method from the intake air with a mixture of ethanol-fuel $(30 \%, 40 \%$, and $50 \%)$ has never been examined and experimental studies have not been carried out. The researchers managed to resolve this gap in the literature with this research. The other motivational point of this research is replacing some fossil fuels with ethanol due to health and environmental problems related to humans. The main objective of this research is to direct these subjects together and carry out hydroxy gas enrichment without forming structural changes in the test machine. In such manner, the dropping of performance resulting from the use of alternative fuel mixture can be improved and tolerated.

\section{The setup of experiment and test procedure.}

\section{HHO generator}

The HHO generator performed in this research is shown in Figure 1. It contains of a separation tank (1) which stores HHO cells (2) with a continuous flow of water to avoid increasing the temperature inside the cell and to supply continual generation of hydrogen. The oxygen-hydrogen blends produced from the dry cell will return to the topside of the tank with a few drops of water. Water droplets are released and fall to the bottom of the tank with the remaining water (3), while hydrogen and oxygen gas are called engine intake manifolds (4). The flow rate of HHO is quantified by calculating the water transfer per time according to the settings shown in Figs. 1. HHO gas releases the separation tank and flows into an open pool of water that carries water downward from an inverted multilevel cylinder. The volume of gas collected in the measuring cylinder per second is calculated as the flow rate of $\mathrm{HHO}$. 


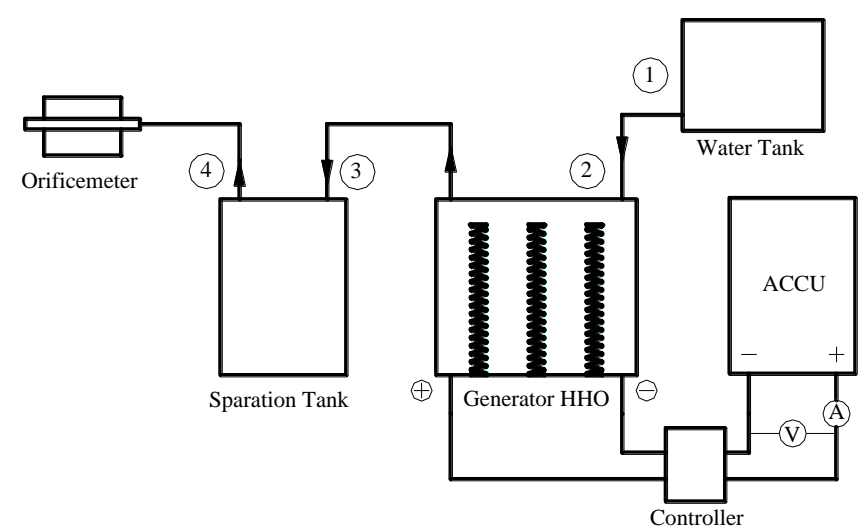

Figure 1. The Illustration of the HHO gas generation system.

\section{Fuels Test.}

Four testing fuels were used in this study. The trait of experimental fuel conducted in Table 1 . The first fuel (E0) is comm gasoline with Research Octane Number (RON) of 92, which is also applied as a reference fuel and base fuel for the composition of the ethanol-gasoline mixture; Other fuels (E30, E40, E50) are gasoline-ethanol blends which contain 30\%, 40\% and 40\% v / v ethanol respectively. The ethanol used for the composition of this mixture is moisture less. Table 1. clearly shows that the addition of ethanol to basic fuel (E0) increases the octane number of the study, viscosity, and heating value of the ethanol-gasoline mixture fuel.

Table 1. The principal properties of the experimented fuels.

\begin{tabular}{cccc}
\hline Fuel Mixture & Viscosity $\left(\mathrm{mm}^{2} / \mathrm{s}\right)$ & Density $\left(\mathrm{g} / \mathrm{cm}^{3}\right)$ & $\begin{array}{c}\text { Low Heating Value } \\
(\mathrm{kJ} / \mathrm{kg})\end{array}$ \\
\hline E0 & 0,51 & 0,732 & 44472 \\
E30 & 0,54 & 0,774 & 37251 \\
E40 & 0,56 & 0,781 & 35134 \\
E50 & 0,58 & 0,791 & 32099 \\
\hline Reference & ASTMD 445-97 & ASTM D-1298 & ASTM D-240 \\
\hline
\end{tabular}

The ethanol-gasoline studied combines fuel with $0 \%, 5 \%, 10 \%, 20 \%$, and $30 \%$ ethanol on the performance and emissions of engines. The study was attended in different engine speeds (range 1000 to $4000 \mathrm{rpm}$ ) along with throttle valve opening in the range of $0 \%$ to $100 \%$ with an increase of $20 \%$. They found that a higher ethanol percentage caused a decrease in the heating value of the fuel. The gasoline-ethanol mixture supplies marginal magnification of the torque output and specific consumption, as opposed to gasoline. Applying gasoline-ethanol fuel mixtures can significantly limit emissions of $\mathrm{CO}$ pollutants and hydrocarbons. Because the ethanol content contains complete combustion, $\mathrm{CO} 2$ emissions are increased, NOX emissions are not delayed on content of ethanol. By using identical machines [10]. The gasoline-ethanol blend fuel was investigated with $35 \%$, and $45 \%$ ethanol on SI engine performance. The study was taken by distinguishing engine speed (range 4000 to $10000 \mathrm{rpm}$ ) and was used for comparing the spark plugs [11].

\section{Engine}

The principal specification of the engine used in the research are shown at Table 2 below. This hiperformance motorcycle is provided with a 4-stroke engine and with a $110 \mathrm{~cm}^{3}$ displacement and spark plug platinum-type ground-electrode used. 
Table 2. Specification of Experimented Engine.

\begin{tabular}{ll}
\hline Type of Engine and Displacement $\left(\mathrm{cm}^{3}\right)$ & $:$ Four Stroke, 109,5 \\
System of Fuel & $:$ Programmed Fuel Injection (PGM-FI) \\
System of Cooling & $:$ Air Cooling \\
Maximum Power $(\mathrm{KW})$ & $: 6,6 \mathrm{KW} / 7500 \mathrm{RPM}$ \\
Combustion Ratio & $: 10 / 1$ \\
Coupling System & $:$ Multiplate Wet Clutch with Coil Spring \\
Weight (Kg) & $: 90 \mathrm{Kg}$ \\
Type of Transmission & $: 4$ Speed Manual, rotary \\
\hline
\end{tabular}

This engine is comfortable with a highly efficient electronic fuel injection (FI) system, letting fuel control including along with increasing efficiency of catalyst as well as in cold transients. The onboard ECU regulates fuel injection revenue by feedback signals coming from the lambda probe oxygen sensor, located in the tube disposal. Under these conditions, the consequences of adding ethanol to pollutant emissions were studied for all. verified fuel under main fuel injection [12]. Most of the modifications are identified to connect to the object and the electrode configuration. At present, insulators are produced from sintered alumina. The cathode has a copper core for escalating thermal conductivity. The surface can be mixed with platinum, gold and silver to increase resistance to hitemperature corrosion. Anodes undergo hi-temperature corrosion by electro-erosion and combustion gasses by sparks that carry metal ions in the plasma state. The nickel alloys were mainly applied, although platinum alloys are located in hi-performance fuse. [13].

\section{Engine Test.}

Bench roller test measurements were carried out at the Surabaya Adhi Tama Institute of Technology. The engine under examination was performed on a single wheel chassis dynamometer (SportDyno3.8-single roller) that reproduces engine resistance along with load of road (Fig.2). The studies were carried out by varying speeds of engine (within range of 4000 to $9000 \mathrm{rpm}$ ). The bench was designed for producing road load requirements and for assessing emissions by dynamic speed cycles. By proceeding this chassis dynamometer, it is possible to take experimental tests in nonconstant mode of speed, mode of traction force, and acceleration mode. Furthermore, the variable speed of blower, which is placed before the vehicle, is carried out as a wind on the road. Help the user present a trail of driving cycle speeds that occur with a tolerance of $1000 \mathrm{rpm}$.

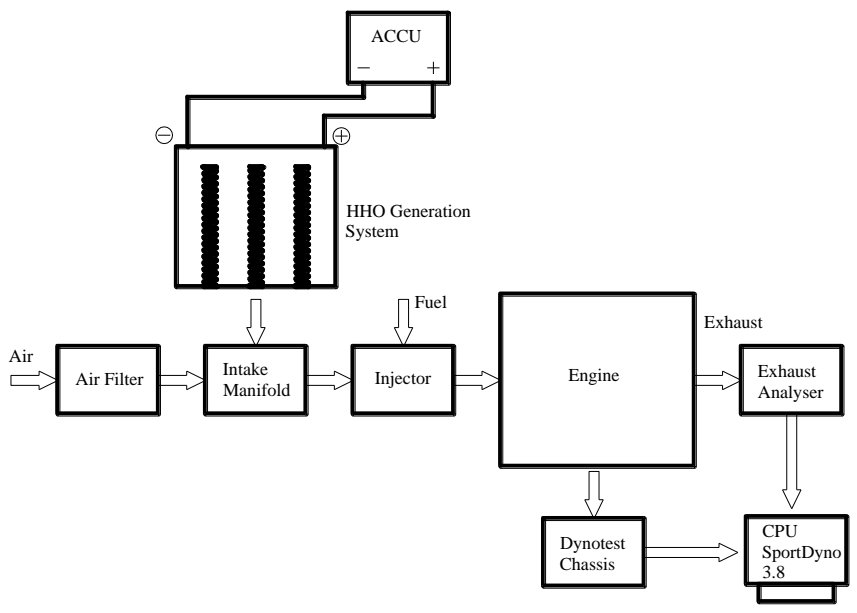

Figure 2. The instrument of experimental set up. 


\section{Result And Discussion.}

Power is determined as the machine's ability to do a performance. In an I.E engine, due to the filling rate in the chamber is less and the conditions of combustion become substandard in high speed and low, low power. Thus, the highest efficient activity situations are achieved at moderate speeds. According to the experiments, it was discovered that when the ratio of ethanol-HHO combined to the gasoline increased, the engine experienced difficulties. Likewise, at speeds above $8000 \mathrm{rpm}$, the engine operates low regularly. The alteration in power concerning the number of rotations per minute when the throttle is fully open from the test engine run is given in Figure 3a. Based on experimental outcomes, engine power has a greatest value at $7200 \mathrm{rpm}$ for E50-HHO mixture. The least value is measured at $9000 \mathrm{rpm}$ with E0 fuel. The graph express that engine power increased about $4 \%$ of E30$\mathrm{HHO}, 4 \%$ of E40-HHO, and 5\% of E50-HHO compared with gasoline. Previous studies showed that the use of ethanol-fuel has increased vehicle power by 2-3\% [7]. In this study, it was known that the critical engine speed was around $7200 \mathrm{rpm}$ into the measurement of power for all types of fuel. In this study, the engine load was modified by a dynamometer that determined engine power was reduced due to a decrease in volumetrical efficiency at engines below and above the critical engine speed. The change in average effective pressure (Mep) concerning revolutions per minute is given in Figure $3 \mathrm{~b}$. In this study, effective engine pressure is best measured with E50-HHO fuel at all test speeds. Following the lower thermal value of the ethanol-HHO mixture in comparision with gasoline, the torque reduction affects power of engine. In research for all fuels which are under effective pressure measured due to increased engine speed, it is resolved that engine pressure rises by the amount of force by unit area.

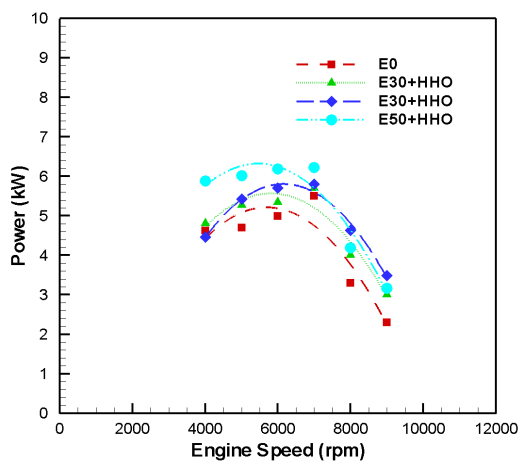

(a)

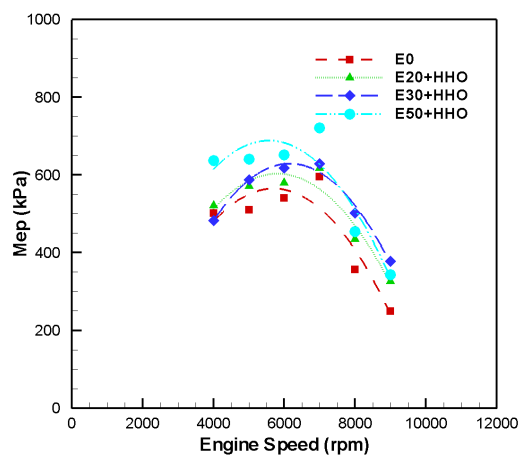

(b)

Figure 3. a. variation of power with engine speed b. variation of Mep with engine speed.

Changes in the SFC mixture of HHO-ethanol in diverse engine speeds in this research are shown in Figure 4a. In the experiments applied, it was resolved that, because the reduced thermal value of HHO-ethanol was less than gasoline (E0), the maximum SFC was seen with the E0 mixture at 9000 $\mathrm{rpm}$ and the lowest with E50-HHO at $7200 \mathrm{rpm}$. The graph shows that specific fuel consumption is reduced by around 5\% for $\mathrm{E} 30-\mathrm{HHO}, 5 \%$ for $\mathrm{E} 40-\mathrm{HHO}$, and $6 \%$ for $\mathrm{E} 50-\mathrm{HHO}$ compared to gasoline. Previous research have shown that ethanol-fuel use has reduced specific vehicle fuel consumption by $3-4 \%$ [7]. The allocation of ethanol in the fuel mixture affects the test engine specific fuel consumption. Because the lower thermal value of gasoline is approximately 1.8 times higher than ethanol, because the ratio of ethanol in the mixture increases (E30-HHO, E40-HHO, E50-HHO), it is known that specific fuel consumption increases to keep the same output power from engine. The alteration in speed at which the maximum engine power is acquaired in an internal combustion engine is allowed to be the utmost efficient variation of work. In this variation, the fact that high combustion and volumetric efficiency reduces specific fuel utilization and rises engine power. In an internal combustion engine, essential efficiency is the value of the tranformation of heat energy acquaried by blazing a fuel mixture into practical energy. The essential efficiency in HHO-ethanol includes test fuel further down than E50-HHO as shown in Figure 4b. 


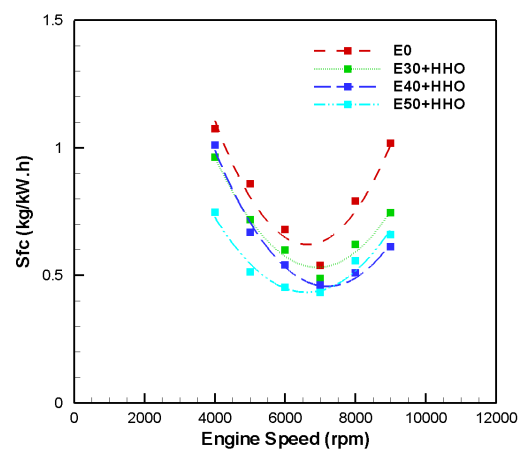

(a)

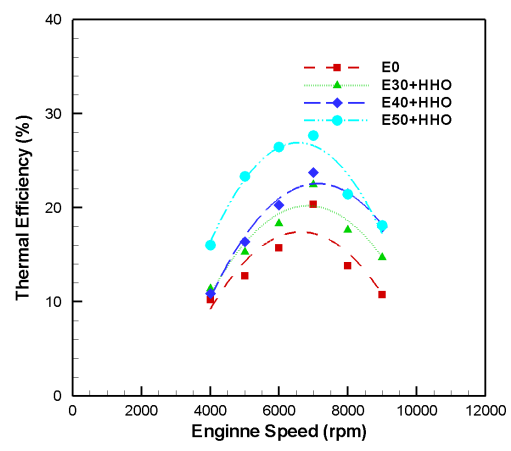

(b)

Figure 4. a. SFC variation with engine speed $b$. Thermal efficiency variation with engine speed

\section{Conclusion.}

This study developed characteristics of single-cylinder I.C engine performance. Type of engine that has been used is a four-stroke cycle single-cylinder with $109,5 \mathrm{~cm}^{3}$ engine volume, the ratio of compression is 10:1. port fuel injection, and 92 RON (Research Octane Number) of gasoline. The gasoline-ethanol-HHO mixtures are E30, E40, and E50 (range of 30\%, 40\%, and 50\%). According to this research, the conclusions are:

1. Ethanol-gasoline-HHO is an excellent candidate as a new alternative solution of fuel.

2. Suitable alterations in the combustion cylinder along with a finer cooling mechanism; Platinum spark plug electrodes will intensify the chance of using a mixture of gasoline-ethanol-HHO over an extensive operating span.

3. Highest power, thermal efficiency, and MEP values obtained in the ethanol-gasoline-HHO (E50) mixture at the operating position with values of $6.22 \mathrm{~kW}, 680.32 \mathrm{kPa}$ and $28.12 \%$ with 7200 engine rpm conditions.

At various power conditions, the spark ignition system can give diverse results with a mixture of gasoline-ethanol-HHO along with diverse spark fuse electrode. Mixture of fuel along with spark fuse electrode mostly affect the work performance of engine. Therefore, it was depending on the structure of the engine (volume, compression ratio, ignition system, number of cylinders, etc.). This must be considered in future research.

\section{References}

[1] M. M. El-Kassaby, Y. A. Eldrainy, M. E. Khidr, and K. I. Khidr, "Effect of hydroxy (HHO) gas addition on gasoline engine performance and emiss ions," Alexandria Eng. J., vol. 55, no. 1, pp. 243-251, Mar. 2016, doi: 10.1016/j.aej.2015.10.016.

[2] A. Boretti, "Comparison of fuel economies of high efficiency diesel and hydrogen engines powering a compact car with a flywheel based kinetic energy recovery systems," Int. J. Hydrogen Energy, vol. 35, no. 16, pp. 8417-8424, Aug. 2010, doi: 10.1016/j.ijhydene.2010.05.031.

[3] C. M. White, R. R. Steeper, and A. E. Lutz, "The hydrogen-fueled internal combustion engine: a technical review," Int. J. Hydrogen Energy, vol. 31, no. 10, pp. 1292-1305, Aug. 2006, doi: 10.1016/j.ijhydene.2005.12.001.

[4] A. C. Yilmaz, E. Uludamar, and K. Aydin, "Effect of hydroxy (HHO) gas addition on performance and exhaust emissions in compression ignition engines," Int. J. Hydrogen Energy, vol. 35, no. 20, pp. 11366-11372, Oct. 2010, doi: 10.1016/j.ijhydene.2010.07.040.

[5] C. Ji and S. Wang, "Effect of hydrogen addition on combustion and emissions performance of a spark ignition gasoline engine at lean conditions," Int. J. Hydrogen Energy, vol. 34, no. 18, pp. 7823-7834, Sep. 2009, doi: 10.1016/j.ijhydene.2009.06.082. 
[6] C. Ji, S. Wang, and B. Zhang, "Effect of spark timing on the performance of a hybrid hydrogengasoline engine at lean conditions," Int. J. Hydrogen Energy, vol. 35, no. 5, pp. 2203-2212, Mar. 2010, doi: 10.1016/j.ijhydene.2010.01.003.

[7] A. A. A. Gatot Setyono, "Effect Of Ethanol-Gasoline Mixes On Performances In Last Generation Spark-Ignition Engines Within The Spark-Plug No Ground-Electrodes Type," Mek. J. Tek. Mesin, vol. 5, no. 2, pp. 19-26, 2020, [Online]. Available: https://jurnal.untagsby.ac.id/index.php/MEKANIKA/article/download/3003/pdf.

[8] M. K. Baltacioglu, R. Kenanoglu, and K. Aydın, "HHO enrichment of bio-diesohol fuel blends in a single cylinder diesel engine," Int. J. Hydrogen Energy, vol. 44, no. 34, pp. 18993-19004, Jul. 2019, doi: 10.1016/j.ijhydene.2019.02.060.

[9] T. Nabil and M. M. Khairat Dawood, "Enabling efficient use of oxy-hydrogen gas (HHO) in selected engineering applications; transportation and sustainable power generation," J. Clean. Prod., vol. 237, p. 117798, Nov. 2019, doi: 10.1016/j.jclepro.2019.117798.

[10] W. D. Hsieh, R. H. Chen, T. L. Wu, and T. H. Lin, "Engine performance and pollutant emission of an SI engine using ethanol-gasoline blended fuels," Atmos. Environ., vol. 36, no. 3, pp. 403410, 2002, doi: 10.1016/S1352-2310(01)00508-8.

[11] Y. P. H. S. Gatot Setyono, "Efek Penambahan Bahan Bakar Research Octane Number (RON) 90-Ethanol Dengan Pemakaian Busi Tipe Dingin Terhadap Performansi Mesin Matic $115 \mathrm{cc}$ 1 Silinder.," Saintek, vol. 16, no. 1, pp. 51-56, 2019.

[12] L. C. M. Sales and J. R. Sodré, "Cold start emissions of an ethanol-fuelled engine with heated intake air and fuel," Fuel, vol. 95, pp. 122-125, May 2012, doi: 10.1016/j.fuel.2011.11.067.

[13] G. Setyono, D. K.-V. 11, N. 2, undefined Desember, and undefined 2014, "Pengaruh Penggunaan Variasi Elektroda Busi terhadap Performa Motor Bensin Torak 4 Langkah," dev2.kopertis7.go.id, Accessed: Sep. 19, 2019. [Online]. Available: http://dev2.kopertis7.go.id/uploadjurnal/Saintek $\quad$ Vol 11 No 2 Des 2014_siap cetak.pdf\#page $=25$. 